\title{
Isolation and identification of oleaginous endophytic fungi
}

\author{
Jie Xie, Lingling Song, Xinran Li, Qian Wu, Chuan Wang, Hui Xu, Yi Cao* and Dairong Qiao* \\ Microbiology and Metabolic Engineering Key Laboratory of Sichuan Province, College of life Science, Sichuan \\ University, Chengdu, Sichuan 610065, China.
}

Accepted 29 March, 2013

\begin{abstract}
Endophytic fungi are a rich source of novel organic compounds with interesting biological activities and a high level of biodiversity. A total of 76 endophytic fungus strains were isolated from 13 species of plants. Through a preliminary screening and fermentation assay, a fungi named ML-GEN.1 isolated from Strobilanthes cusia was found and the lipid content reached $59 \%$. This is the first report of oleaginous microorganism which is isolated from S. cusia. ML-GEN.1 was identified as Fusarium sp.ML-GEN.1 through morphological and molecular methods. Similar to vegetable oils, the fatty acid composition of lipid from Fusarium sp. ML-GEN.1 contained oleic acid (41.66\%), palmitic acid (23.26\%), linoleic acid $(19.18 \%)$, and the unsaturated fatty acids amounted to about $61 \%$. In waste molasses fermentation, Fusarium sp. ML-GEN.1 accumulated lipid to $29 \%$ of biomass when various sugars in waste molasses were utilized as the carbon source. The biomass was $22.8 \mathrm{~g} / \mathrm{L}$, which was much higher than the original value $(12.7 \mathrm{~g} / \mathrm{L})$.
\end{abstract}

Key words: Oleaginous endophytic fungi, biodiesel, waste molasses.

\section{INTRODUCTION}

Bio-diesel fuels defined as fatty acid methyl esters derived from various renewable lipid resources (for example rapeseed oil, soybean oil, palm oil, etc.) is an appropriate alternative to petroleum-based diesel (Hirschmann et al., 2005). The employ of oleaginous microbial for the production of biodiesel (fatty acid methyl esters; FAME) has been described as one of the most promising ways with the potential to meet fossil diesel replacement targets without encroaching on arable land suitable for food production. Microbes accumulate more than $20 \%$ lipids in their cells in the form of triacylglycerols which were called oleaginous microorganism (Certik, 1999). Various agroindustrial residues, molasses (Zhu et al., 2008), methanol (Rupčić et al., 1996), orange peel (Gema et al., 2002), monosodium glutamate (Xue et al., 2006), sewage sludge (Angerbauer et al., 2008), starch (Papanikolaou et al., 2007) and pectin (Papanikolaou et al., 2007), were used for lipid production by different oleaginous micro-organisms.

Endophytes are microorganisms that reside within inter- nal tissues of living plants without visibly harming the host plant (Fisher and Petrini, 1987). Some endophytic fungi have been found to produce similar chemical compounds to those produced by its host (Aly et al., 2010). Others have been shown to be potential source of novel natural products useful in medicine, agriculture and industry (Schulz et al., 2002; Rodriguez et al., 2009; Aly et al., 2010; Lin et al., 2010a; Flor et al., 2011).

We will focus on endophytic fungi as sources of lipid resources, including aspects of their interaction with the host plants, methods for isolation, preservation, identification and culturing, as well as endophytic fungi and recently isolated novel structures.

\section{MATERIALS AND METHODS}

Oil plants, peanut plant, rape, soybean, sunflower, sesame, cotton plant, and Perilla, Jatropha, were collected from Sichuan and Hebei of China. Chinese medicinal plants, Rabdosia nervosa, Vitex trifolia, 
Platycodongrandiforus, AconitumcarmichaeliDebx, and Strobilanthes cusia were collected in the Medicinal Botanical Garden of Huaxi, Sichuan University. Samples were immediately placed in plastic bags, stored at $4^{\circ} \mathrm{C}$ and processed within 2 days of collection.

\section{Isolation of endophytic fungi}

The plant materials were washed in running tap water, followed by several rinses in sterile distilled water and then cutting into $3-\mathrm{cm}$ fragments. The plant fragments were surface sterilized by immersion in $75 \%$ ethanol for 15 min and washed three times with sterilized distilled water. Leaves and stems were ground in the sterilized mortar with $1 \mathrm{~mL}$ sterile distilled water. Samples of the suspensions were submitted to serial dilutions, which were inoculated into 90 $\mathrm{mm}$ Petri dishes with selected media $(\mathrm{g} / \mathrm{L})$ : glucose, $5 \mathrm{~g}$; yeast extract, $1 \mathrm{~g}$; peptone, $3 \mathrm{~g}$; $\mathrm{ZnSO}_{4}, 0.01 \mathrm{~g} ; \mathrm{NaHCO}_{3}, 1 \mathrm{~g}$; disodium EDTA, $0.1 \mathrm{~g}$; sodium glutamate, $1 \mathrm{~g}$; $\mathrm{MgSO}_{4} \cdot 7 \mathrm{H}_{2} \mathrm{O}, 0.08 \mathrm{~g}$; ferric citrate, $0.01 \mathrm{~g} ; \mathrm{CaCl}_{2} \cdot 2 \mathrm{H}_{2} \mathrm{O}, 1 \mathrm{~g}, \mathrm{~K}_{2} \mathrm{HPO}_{4}, 0.6 \mathrm{~g}$; agar $2 \mathrm{~g} ; \mathrm{H}_{2} \mathrm{O} 1000$ $\mathrm{mL} ; 20 \mu \mathrm{g} / \mathrm{mL}$ Streptomycin at original $\mathrm{pH}$.

The roots were cut into pieces $(1 \times 1 \mathrm{~cm})$ and then evenly placed on the surface of the selected media. To confirm the sterilization efficiency, the last washing water was inoculated into Petri dishes. The Petri dishes where incubated at $28^{\circ} \mathrm{C}$ for 15 days and checked daily. A hyphal tip of the endophytic fungus appearing on the plate was removed, made pure, subcultured and kept in Glycerin at $80^{\circ} \mathrm{C}$.

\section{Lipid content test}

Mycelium of each strain was stained by immersing in Sudan black (Burdon, 1946) for $8 \mathrm{~min}$, immediately rinsed with $70 \%$ ethanol for 5 $\mathrm{s}$, and then Observed under the light microscope (Figure 1a). Stain which had dark blue lipid particles in its mycelium was selected for further study of lipid content.

The 3-days-old cultures in the seed medium ( $5 \mathrm{~g} / \mathrm{L}$ peptone, $2 \mathrm{~g} / \mathrm{L}$ yeast extract, $20 \mathrm{~g} / \mathrm{L}$ glucose, $3 \mathrm{~g} / \mathrm{L} \mathrm{KH}_{2} \mathrm{PO}_{4}, 1.5 \mathrm{~g} / \mathrm{L} \mathrm{MgSO}$, and $\mathrm{pH} 6.2$ to 6.6) were transferred into $100 \mathrm{~mL}$ nitrogen-limited culture medium (Lin et al., 2010b) (100 g/L glucose, $1.5 \mathrm{~g} / \mathrm{L}$ yeast extract, $0.5 \mathrm{~g} / \mathrm{L}\left(\mathrm{NH}_{4}\right)_{2} \mathrm{SO}_{4}, 1 \mathrm{~g} / \mathrm{L} \mathrm{MgSO}_{4} \cdot 7 \mathrm{H}_{2} \mathrm{O}, 7 \mathrm{~g} / \mathrm{L} \mathrm{KH}_{2} \mathrm{PO}_{4}, 2.5 \mathrm{~g} / \mathrm{L}$ $\mathrm{NH}_{4} \mathrm{NO}_{3}, 0.2 \mathrm{~g} / \mathrm{L} \mathrm{CaCl} 2 \cdot 2 \mathrm{H}_{2} \mathrm{O}, 0.01 \mathrm{~g} / \mathrm{L} \mathrm{FeSO}_{4} \cdot 7 \mathrm{H}_{2} \mathrm{O}, 0.01 \mathrm{~g} / \mathrm{L}$ $\left.\mathrm{ZnSO}_{4} \cdot 7 \mathrm{H}_{2} \mathrm{O}, 0.001 \mathrm{~g} / \mathrm{L} \mathrm{MnSO}_{4} \cdot 4 \mathrm{H}_{2} \mathrm{O}, 0.0005 \mathrm{~g} / \mathrm{L} \mathrm{CuSO} \cdot 5 \mathrm{H}_{2} \mathrm{O}\right)$ in the $250 \mathrm{~mL}$ shake-flasks, and grown at $150 \mathrm{rpm}$ and $28^{\circ} \mathrm{C}$. After 7 days of growth, cultures were harvested by centrifugation at 12000 rpm, at $5 \mathrm{~min}$.

The cell wall of the mycelia was broken by modified acid-heating extraction (Schulz et al., 2002). $4 \mathrm{M} \mathrm{HCl}$ was added to the biomass in a ratio of $1: 6(\mathrm{w} / \mathrm{v})$, and the mixture was heated in boiling water for $10 \mathrm{~min}$ with periodic vortex homogenization. Subsequently, freezing at $-80^{\circ} \mathrm{C}$ for $20 \mathrm{~min}$ was done. This process was repeated for three times, followed by centrifugation at $6000 \mathrm{rpm}$ for $10 \mathrm{~min}$. The sediment sample was dried at $65^{\circ} \mathrm{C}$ prepared for conventional Soxhlet extraction (Eikani et al., 2007) using ether as media.

\section{Morphological identification of the endophytic fungi}

The fungi was cultured on the PDA plates at $28^{\circ} \mathrm{C}$ for 5 days. The ultrastructure of ML-GEN.1 was studied by the scanning electron microscopy (Kirschner, 2009). The Mycelium of ML-GEN.1 growing on the solid media was cut into $1 \times 1 \times 1 \mathrm{~cm}$. The sample was processed before observing in the scanning electron microscope through the following steps: primary fixation with $2.5 \%$ glutaraldehyde for more than $2 \mathrm{~h}$, post fixation with $4 \%$ glutaraldehyde for $4 \mathrm{~h}$, followed by washing with 0.1 Monophosphate buffer; three changes of 15 min each. Sequential dehydration (Kirschner, 2009) was initially done with $30 \%$ ethanol for $15 \mathrm{~min}$, followed by $50 \%$ ethanol for 15 min, $70 \%$ ethanol for $15 \mathrm{~min}, 80 \%$ ethanol for $15 \mathrm{~min}, 90 \%$ ethanol for $15 \mathrm{~min}$, and $95 \%$ ethanol for $15 \mathrm{~min}$. Critical point drying was done using liquid $\mathrm{CO}_{2}$ at its critical point $\left(31.5^{\circ} \mathrm{C}\right.$ at $1100 \mathrm{PS}$ I. Sputter coating was done using Gold $10 \mathrm{~nm}$ think film coating. The sample was observed in Scanning electron microscopy.

\section{DNA extraction and amplification}

Endophytic fungus ML-GEN.1 was identified on the basis of microscopic morphology and nucleotide sequence of ribosomal RNA. Genomic DNA was extracted from fungal mycelia using the Plant Genomic DNA Kit (TIANGEN, China) according to the manufacturer's instructions. PCR primers ITS86 (GTGAATCATCGAATCTTTGAAC) and ITS4 (TCCTCCGCTTATTGATATGC) were used to amplify the ITS2 sequence from the fungal chromosomal DNA (Life Technologies, Barcelona, Spain). Final concentrations for $25 \mu \mathrm{L}$ PCR reactions were as follows: $5 \mathrm{~min}$ at $94^{\circ} \mathrm{C}$ followed by 30 cycles of $50 \mathrm{~s}$ at $94^{\circ} \mathrm{C}, 50 \mathrm{~s}$ at $51^{\circ} \mathrm{C}$, and 2 min at $72^{\circ} \mathrm{C}$ with a final extension period of $10 \mathrm{~min}$ at $72^{\circ} \mathrm{C}$. The amplified DNA was purified using the Universal DNA Purification Kit (TIANGEN, China) according to the manufacturer's protocol. The purified PCR products were cloned into pMD19-T vector (Takara, Japan) in accordance with the manual, and transformed into Escherichia coli JM109 competent cells (Sambrook and Russell, 2001). The recombinant plasmid DNA was purified and sequenced. For tentative identification, ITS rDNA sequences were compared with NCBI (http://www.ncbi.nlm.nih.gov) database.

\section{Phylogenetic analysis}

MEGA 5.0 was used in this study (Tamura et al., 2007). Fungal rDNA - ITS sequence of ML-GEN. 1 and the matched sequences from GenBank were edited and aligned .

Neighbour-joining (NJ) trees were created using Kimura twoparameter distances. The quality of the branching patterns for $\mathrm{NJ}$ was assessed by bootstrap resampling of the data sets with 1,000 replications.

\section{Fatty acid methyl ester (FAME) analysis}

The crude lipids which were obtained from the fungus cells was solved in hexane and transesterified to biodiesel by base catalysis with $2 \mathrm{~N} \mathrm{KOH}$ dissolved in methanol, followed by $5 \mathrm{~mL}$ water and placed in $30^{\circ} \mathrm{C}$ for $15 \mathrm{~min}$ to stratify. The layer of hexane were introduced directly into the GC MS-QP2010 Gas chromatograph mass spectrometer equipped (Shimadzu Corporation) with Rtz-Wax column $(30 \mathrm{~m} \times 0.25 \mathrm{~mm} \times 0.25 \mathrm{~m})$. Helium was used as the carrier gas. Temperature was $160-230^{\circ} \mathrm{C} ; 10^{\circ} \mathrm{C} / \mathrm{min}$ and the sample volume was $0.4 \mu \mathrm{L}$; split $1: 80(\mathrm{v} / \mathrm{v})$.

\section{Waste molasses fermentation}

Cane molasses was obtained from Lutang Sugar refinery (Guangxi, China). Molasses media was as follows: $20 \%$ molasses solution, $1.5 \mathrm{~g} / \mathrm{L}$ yeast extract, $0.5 \mathrm{~g} / \mathrm{L}\left(\mathrm{NH}_{4}\right)_{2} \mathrm{SO}_{4}, 1 \mathrm{~g} / \mathrm{L} \mathrm{MgSO}{ }_{4} \cdot 7 \mathrm{H}_{2} \mathrm{O}, 7 \mathrm{~g} / \mathrm{L}$

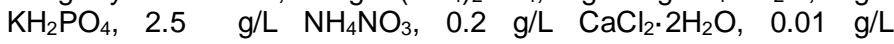
$\mathrm{FeSO}_{4} \cdot 7 \mathrm{H}_{2} \mathrm{O}, 0.01 \mathrm{~g} / \mathrm{L} \quad \mathrm{ZnSO}_{4} \cdot 7 \mathrm{H}_{2} \mathrm{O}, 0.001 \mathrm{~g} / \mathrm{L} \quad \mathrm{MnSO}_{4} \cdot 4 \mathrm{H}_{2} \mathrm{O}$, $\mathrm{CuSO}_{4} \cdot 5 \mathrm{H}_{2} \mathrm{O} 0.0005 \mathrm{~g} / \mathrm{L}$, and $\mathrm{pH}$ 6.5. The crude molasses was pretreated with $\mathrm{H}_{2} \mathrm{SO}_{4}$ according to the reported method (Yu et al., 2008). Un-pretreated molasses was added to the fermentation media as a comparison. 

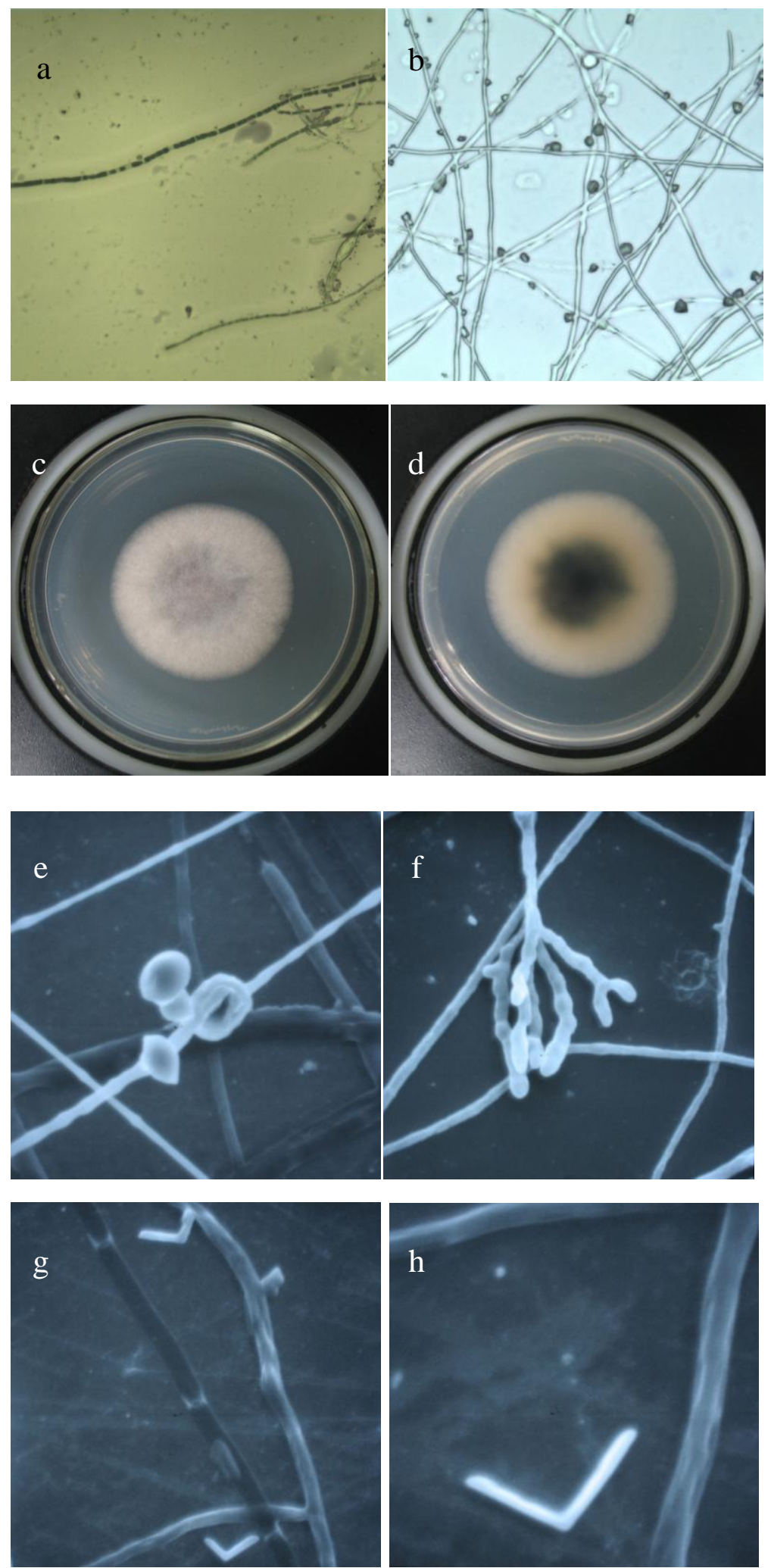

Figure 1. Morphological examination of strain ML-GEN.1. a, b, Light micrograph ( $\times 40$ magnification) of a Sudan black staining hyphae (a) and chlamydoconidia (b) originated from hyphae. c, d, The obverse (c) and reverse (d) of colonies of ML-GEN.1 growing on a PDA plate for 5 days. eh Scanning electron micrograph of chlamydoconidia (e), conidiophores ( $f$ ) and conidia $(g, h)$. 
Table 1. Results of waste molasses fermentation.

\begin{tabular}{lccc}
\hline Characteristic & Un-pretreated waste molasse & Pretreated waste molasse & Nitrogen-limited culture medium \\
\hline Lipid content $(\%)$ & 31 & 29 & 59 \\
Biomass $(\mathrm{g} / \mathrm{L})$ & 15.5 & 22.8 & 12.7 \\
Lipid Production $(\mathrm{g} / \mathrm{L})$ & 4.085 & 6.612 & 7.493 \\
\hline
\end{tabular}

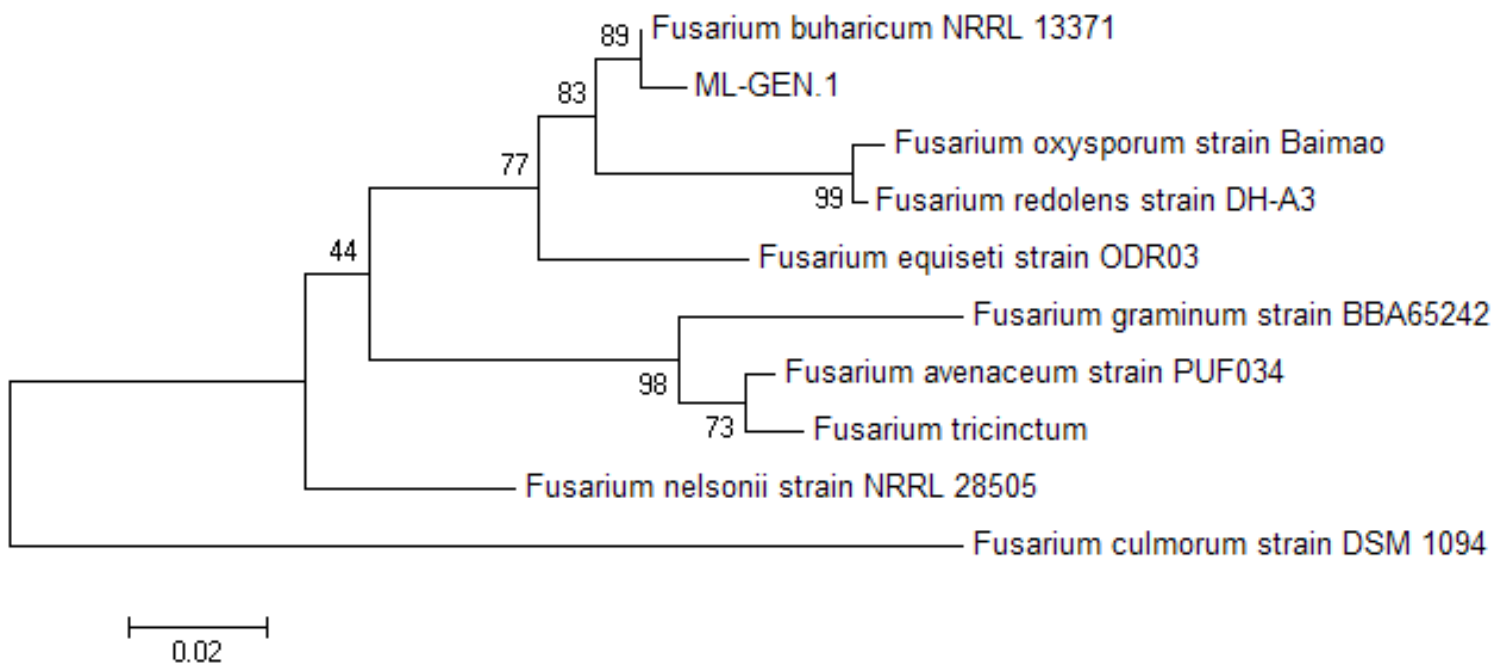

Figure 2. Neighbor-joining tree of ML-GEN.1 based on 5.8S-ITS2-28S rDNA sequences. Confidence values above $50 \%$ obtained from a 1000 -replicate bootstrap analysis are shown at the branch nodes. Bootstrap values from the neighbor-joining method were determined.

\section{RESULTS AND DISCUSSION}

\section{Isolation of endophytic fungi}

A total of 76 strains of oil-producing fungi were isolated from plant samples, and each was dyed by Sudan Black and tested for its capability to produce lipid. The isolate ML-GEN.1 produced the highest level of oil with its lipid content of $59 \%$ and the biomass of $12.7 \mathrm{~g} / \mathrm{L}$. Figure 1a shows there were large amounts of lipid in mycelia cells, which indicated ML-GEN.1 was possibly with high lipid content.

\section{Morphological identification of ML-GEN.1}

Colonies of strain ML-GEN. 1 grew rapidly; $5 \mathrm{~cm}$ in 5 days on a PDA plate. The colony had a cottony aerial mycelium, with a color of white to blue (Figure 1c, d).

The results show the light and scanning electron microscopic studies of strain ML-GEN.1 (Figure 1b, e-h). The hyphae had rough surface and were always branching. Chlamydospores were terminal, hyaline, smooth, and borne in pairs on short lateral hyphal branches. Conidiophores were short, single and multi-branched. The conidia were sickle-shaped, which were the typical formation for the genus Fusarium. According to these characteristics described above, strain ML-GEN.1 was identified as a definite species of Fusarium sp. It was hard to locate this strain into a named species just from the morphological information. Thus, the molecular identification was employed to identify it.

\section{Molecular identification and phylogenetic analysis of ML-GEN.1}

The isolate ML-GEN.1 that produced the highest level of lipid was taxonomically identified according to the ITS sequence. The ITS sequence was deposited with the National center for Biotechnology Information (NCBI) GenBank under the accession number JN248715. The sequence was aligned with other most identical sequences available in the GenBank and compared with closely related sequences retrieved from the GenBank. It displayed the highest degree of homology with those of Fusarium when it was compared by BLAST analysis to the sequences in the GenBank. The results of phylogenetic analysis suggestthat strain ML-GEN.1 may represent a novel species within the genus Fusarium.

In the neighbor-joining (NJ) tree (Figure 2), strain MLGEN.1 and Fusarium buharicum NRRL 13371 formed a 


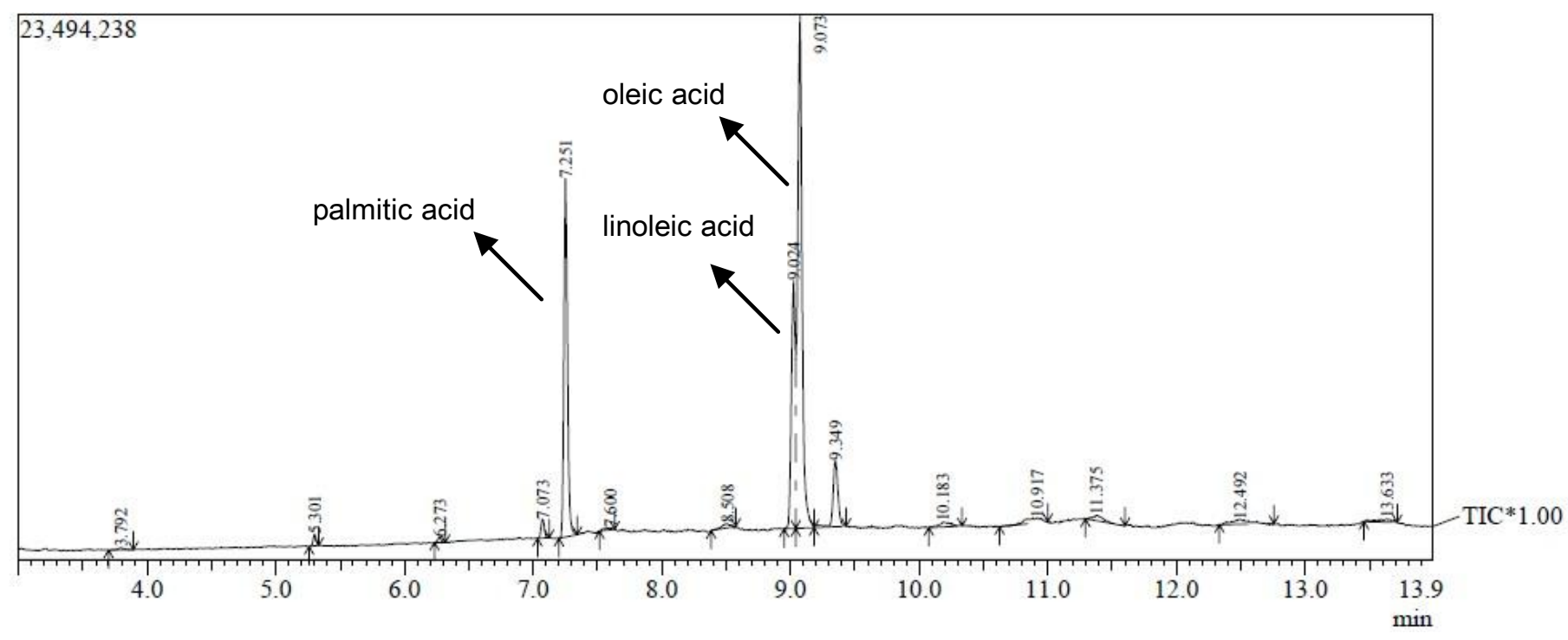

Figure 3. Chromatogram of FAMEs from the lipid of ML-GEN.1.

clade with $89 \%$ bootstrap support. The results of similarity comparisons of the 5.8S-ITS2-28S region sequence revealed that strain ML-GEN.1 had the highest nucleotide similarities with $F$. buharicum NRRL 13371. Referring to the results of the morphological and molecular identification, it could be confirmed that ML-GEN.1 belongs to the genus of Fusarium.

\section{Analysis of grease composition}

GC analysis showed that the lipid extracted from Fusarium sp.ML-GEN.1 mainly contained oleic acid (41.66\%), palmitic acid (23.26\%), linoleic acid (19.18\%), the unsaturated fatty acids amounted to about $61 \%$, and it was rich in oleic acid and linoleic acid (Figure 3 ). The fatty acids profile obtained in this study is similar to that of vegetable oils (Ha et al., 2011).

\section{Waste Molasses Fermentation}

Results of waste molasses fermentation are shown in Table 1. In pretreated waste molasses, a biomass of 22.8 $\mathrm{g} / \mathrm{L}$ and a lipid content of $29 \%$ could be achieved after culture for 7 days. In contrast, a biomass of $15.5 \mathrm{~g} / \mathrm{L}$ and a lipid content of $31 \%$ were got in un-pretreated waste molasses. The lipid content in pretreated waste molasses was similar to un-pretreated waste molasses. However, the biomass in pretreated waste molasses was almost 1.5 -fold that of un-pretreated waste molasses, leading to the lipid production of 1.6-fold. It is obvious that the lipid content obtained with waste molasses was much lower than that with nitrogen-limited culture medium. The relatively low $\mathrm{C} / \mathrm{N}$ molar ratio (about 12.5) was thought to be one of the reasons for this (Zhu et al., 2008).

\section{Conclusions}

We isolated an oleaginous endophytic fungi ML-GEN.1, which was identified as a novel species within the genus Fusarium, which was able to convert the waste molasses into lipid mainly composed of oleic acid, palmitic acid and linoleic acid. The feasibility of efficient and low-cost microbial lipid production by Fusarium sp.ML-GEN.1 from waste molasses was subsequently established. Fusarium sp.ML-GEN. 1 could yield lipid as high as $6.612 \mathrm{~g} / \mathrm{L}$ under the un-optimized conditions.

\section{ACKNOWLEDGMENTS}

This work was supported by the National twelfth five-year science and technology support program (2011BAD14B05, 2013BAD10B01), National Special Basic Research of china (SB2007FY400) and Sichuan Science and Technology Bureau (2010HH0034, 2012GZ0008, 2010GZ0065, 2011GZ0027).

\section{REFERENCES}

Aly AH, Debbab A, Kjer J, Proksch P (2010). Fungal endophytes from higher plants: a prolific source of phytochemicals and other bioactive natural products. Fungal Divers., 41(1): 1-16.

Angerbauer C, Siebenhofer M, Mittelbach M, Guebitz GM (2008). Conversion of sewage sludge into lipids by Lipomyces starkeyi for biodiesel production. Bioresour. Technol., 99: 3051-3056.

Burdon K(1946). Fatty material in bacteria and fungi revealed by staining dried, fixed slide preparations. J. Bacteriol., 52(6):665-678.

Certik M (1999). Effect of nitrogen sources on the activities of lipogenic enzymes in oleaginous fungus Cunninghamella echinulata. Appl. Microbiol., 45: 289-293.

Eikani MH, Golmohammad F, Rowshanzamir S (2007). Subcritical water extraction of essential oils from coriander seeds (Coriandrum sativum L.). J. Food Eng., 80:735-740. 
Fisher PJ, Petrini O (1987). Location of fungal endophytes in tissue of Suaeda fruticosa: a preliminary study. Trans. Br. Mycol. Soc., 89:246-249.

Flor N, Rivera-Orduña (2011). Diversity of endophytic fungi of Taxus globosa (Mexican yew). Fungal Divers., 47:65-74.

Gema H, Kavadia A, Dimou D, Tsagou V, Komaitis M, Aggelis G (2002). Production of c-linolenic acid by Cunninghamella echinulata cultivated on glucose and orange peel. Appl. Microbiol. Biotechnol., 58:303-307.

Ha J, Seo DW, Chen X, Hwang JB, Shim YS (2011). Determination of Hexanal as an Oxidative Marker in Vegetable Oils Using an Automated Dynamic Headspace Sampler Coupled to a Gas Chromatograph/Mass Spectrometer. Anal. Sci., 27:873-878.

Hirschmann S, Baganz K, Koschik I, Vorlop KD (2005). Development of an integrated bioconversion process for the production of 1,3propanediol from raw glycerol waters. Landbauforschung Völkenrode, 55: 261-267.

Kirschner R (2009). Cercosporella and Ramularia. Mycologia, 101(1):110-119.

Lin H, Cheng W, Ding HT, Chen XJ, Zhou QF, Zhao YH (2010a). Direct microbial conversion of wheat straw into lipid by a cellulolytic fungus of Aspergillus oryzae A-4 in solid-state fermentation. Bioresour. Technol., 101(19):7556-7562.

Lin X, Huang Y, Zheng Z, Su W, Qian X, Shen Y (2010b). Endophytes from the pharmaceutical plant, Annona squamosa: isolation, bioactivity, identification and diversity of its polyketide synthase gene. Fungal Divers., 41(1):41-51.

Papanikolaou S, Galiotou-Panayotou M, Fakas S, Komaitis M, Aggelis G (2007). Lipid production by oleaginous Mucorales cultivated on renewable carbon sources. Eur. J. Lipid Sci. Technol., 109:10601070.
Rodriguez RJ, White JF, Arnold AE, Redman RS (2009). Fungal endophytes: diversity and functional roles. New Phytol., 182:314-330.

Rupčić J, Blagović B, and Marić V (1996). Cell lipids of the Candida lipolytica yeast grown on methanol. J. Chromatogr. A.,755:75-80.

Sambrook J, Russell DW (2001). Molecular cloning: a laboratory manual, 3rd edn. Cold Spring Harbo Laboratory Press, Cold Spring Harbor.

Schulz B, Boyle C, Draeger S, Römmert AK, Krohn K (2002). Endophytic fungi: a source of novel biologically active secondary metabolites. Mycol. Res., 106:996-1004.

Tamura K, Dudley J, Nei M, et al., (2007). MEGA4: molecular evolutionary genetics analysis (MEGA) software version 4.0. Mol. Biol. and Evol., 24:1596-1599.

Xue F, Zhang X, Luo H, Tan T (2006). A new method for preparing raw material for biodiesel production. Process Biochem., 41 (7):16991702.

Liu YP, Zheng P, Sun ZH, Ni Y, Dong JJ, Zhu LL (2008). Economical succinic acid production from cane molasses by Actinobacillus succinogenes. Bioresour. Technol., 99:1736-1742. Complete the author name

Zhu L, Zong M, Wu H (2008). Efficient lipid production with Trichosporon fermentans and its use for biodiesel preparation. Bioresour. Technol., 99(16): 7881-7885. 